\title{
4
}

\section{The Emergence of the Socialist Healthcare Model After the First World War}

\section{Andreas Heinrich}

One of the most influential models in healthcare organisation and finance is the so-called Semashko model. While disseminated only regionally, Krementsov $(2017,1693)$ rightly points out that the Semashko system "generated innovations, models, and examples to be emulated or avoided, but certainly not ignored, around the world". The following chapter scrutinises its origins in Russia (and later the Soviet Union) and its expansion to Central and Eastern Europe. Its creation and later its spatial expansion were both by-products of war. The Russian Revolution of October 1917 (brought about by the First World War) was the starting point for the development and introduction of the Semashko model. The first part of this chapter analyses the origin and evolution of the healthcare model in the inter-war period in the Soviet Union. The second part deals with the spatial expansion of the Soviet healthcare model precipitated by the end of the Second World War and the beginning of the Cold War after 1945 when the Semashko model was (forcibly) exported to large parts of

A. Heinrich $(\bowtie)$

University of Bremen, Bremen, Germany

e-mail: heinrich@uni-bremen.de 
Central and Eastern Europe. Even though the initial success of the healthcare model ended in crisis (described in part three), its legacies still influence healthcare policies in this region today.

\section{The First Trigger: First World War and the October Revolution 1917}

Germany's military calculations for ending the First World War on its eastern front against Tsarist Russia enabled the October Revolution in 1917: by ferrying the leadership of the Bolshevik opposition from their exile in Switzerland to Russia, the Germans hoped to install a "friendly" Russian government that would sign an armistice. This war-induced "polity reconfiguration" (Obinger et al. 2018, 12) established a Bolshevik government, which, in turn, was also the starting point for the development and introduction of the socialist Semashko model of healthcare organisation and finance.

While Tsarist Russia had not developed a unified healthcare system, the Bolsheviks aimed to change this. Though short on specifics, Bolshevik leaders had a clear direction for their intended modernisation of the welfare state: the eradication of the Tsarist legacy and the creation of a welfare system along socialist lines. The Bolsheviks aimed at a fundamental social revolution for the material and cultural betterment of the workers. The new social medicine, as opposed to the medical system in the capitalist West, would primarily respond to the medical needs of the proletarian class, including a comprehensive social insurance in the hands of the working class (Rimlinger 1971, 252-257; Solomon and Hutchinson 1990, x; Weissman 1990, 98-99; Williams 2006, 206). It was the general assumption among Bolsheviks that capitalism causes ill health, and that the revolution would ultimately lead to the elimination of disease (George and Manning 1980, 104).

In June 1918, the outlines of the socialist health policy began to emerge. Nikolai A. Semashko, the eponym of the described healthcare model, envisioned the socialist healthcare system as comprehensive, qualified medical care available to everyone in the population free of charge 
and organised as a single, unified service provided by the state. He especially emphasised the importance of extensive preventive care for creating a healthy population. These principles were influenced by international health initiatives: while prophylactic measures were borrowed from British health protection, the class character was inspired by the German health insurance (i.e. different insurance schemes for different occupations). On the domestic side, the idea of free and universally accessible medical care goes back to the Russian zemstvo (local government) medical service (George and Manning 1980, 105-106).

In addition to a free, universal healthcare service, a People's Commissariat of Public Health (Narkomzdrav) was established in July 1918 , one of the first unified and centralised health administrations in the world. Semashko, a trained physician, became its first departmental head (Solomon and Hutchinson 1990, xi; Weissman 1990, 97-98). Dedicated to reason and science, Bolshevik medical administrators elaborated new, "rational" principles of healthcare: "As in the economic sphere, Bolshevik leaders defined rationality in terms of nationwide planning, universally obligatory norms, and technical specialization" (Weissman 1990, 110, quote 116). By ensuring government administration and control, and distributing healthcare through Narkomzdrav, the pitfalls of capitalism, such as the dangers of market fluctuations and volatile funding, were thought to be avoidable (Schecter 1992, 207).

However, already in the first decade, almost all of Semashko's principles were altered. This decade was characterised by a vicious civil war that lasted nearly five years, as the October Revolution caused an armed backlash of anti-Bolshevik forces. In addition to the upheavals and miseries of the First World War, the civil war led to severe destruction and disruption, internal displacements, famines and epidemics. These conditions resulted in an urgent demand for a healthcare system but, simultaneously, in an overall lack of government resources. Additionally, healthcare was a low priority; its financial endowment was subordinated to the war effort and, after the end of the civil war, to demands of the economic sector. The relatively weak and inexperienced health administration in Narkomzdrav "was sometimes forced to adopt measures and programs that ran counter to its desires" (Davis 1990, 148). 
Consequently, the principle of universal access to healthcare based on need was never strictly adhered to. As social need was politically determined, "class" became an important determinant of access. Especially industrial workers from favoured industries were granted preferential medical treatment, while medical networks in the countryside remained rudimentary. Furthermore, despite the rhetoric to the contrary, fees for healthcare existed and rationing of services prevailed (George and Manning 1980, 112; Twigg 1998, 585; Weissman 1990, 113; Williams 2006, 211-12, 216). Additionally, the unification and centralisation of healthcare was difficult to implement due to the sheer size of the Soviet Union (established in 1922), to which the Semashko system was extended: "In many instances reforms trumpeted at the center never penetrated the periphery" (Solomon and Hutchinson 1990, xii). Despite these mostly war-related challenges, Weissman argues $(1990,102)$ that they "did not, however, force the abandonment of the basic principles of the new health system". The principles continued to drive official policy reinforcing the commitment of Narkomzdrav's leadership to those principles. This commitment was tested by the end of the 1920s.

With the rapid industrialisation, forced collectivisation of agriculture and the introduction of the first five-year plans (FYPs) in 1928, "health services were now quite explicitly directed towards industrial effort" (George and Manning 1980, 110). The FYP was also introduced to the healthcare sector to integrate it into the overall national economic plan and "to improve health conditions, increase the food supply, raise labour productivity, stress health and welfare in industrial centres, cut the level of industrial accidents, increase health awareness (sanitary culture) and maintain a unified dispensary system" (Williams 2006, 213). Contrary to the intentions of Narkomzdrav, the Bolshevik leadership saw the healthcare sector only as a means to an end, subordinated to the economic sector and primarily for the benefit of industrial workers.

This not only steered the healthcare system further away from its original principles, but also had an adverse effect on health conditions in the country. The sector was not able to cope with the very problems generated by industrialisation and collectivisation (such as work-related accidents, sanitation problems, unhealthy working conditions) due to cuts in health and welfare spending. The situation was worsened by setting 
unrealistic health and welfare targets in the overall national FYP. Consequently, even in Moscow and other privileged industrial regions, medical care deteriorated (Davis 1990, 149; George and Manning 1980, 109; Williams 2006, 213-214).

In this situation, Bolshevik decision-makers became convinced that "special measures would have to be implemented to protect the medical care of the industrial proletariat from adverse consequences of economic disruptions" (Davis 1990, 150). Consequently, Narkomzdrav's first proposal for an FYP for health in 1929 was criticised for its "failure to incorporate a 'proletarian class line' in distributional plans" (Davis 1990, 154). Instead of distributing medical care primarily on the basis of need, critics of the proposal "called for the rapid growth of a medical system oriented to providing care at the place of work, with preference given to patients in those socioeconomic groups deemed most important by political authorities" (Davis 1990, 147). Thus, these critics argued for an official non-egalitarian health policy contradicting the principles of the Semashko system. To overcome its inherent reluctance towards class politics, the Narkomzdrav was purged; in January 1930, Semashko was relieved of his responsibilities as People's Commissar of Public Health and a more ambitious, class-oriented FYP for health was adopted (Davis 1990, 147, 156).

Still, by the 1930s, the Semashko healthcare system was largely in place. The entire Soviet health service was organised across a number of administrative tiers, from the national to the regional, city and district levels. Four layers of healthcare facilities existed: hospitals, polyclinics, primary healthcare, and sanitary epidemiological (public health) centres. These facilities were often funded from separate budgets, leading to the duplication of functional responsibilities. Originally introduced as a twoway planning and decision-making process, "the allocation process in the central Health Ministry in Moscow (determined) health care resources and funding at all levels" (Rowland and Telyukov 1991, 77). Soviet plan targets for healthcare created inappropriate incentives:

Hospitals were funded according to their success in fulfilling a centrally set plan for numbers of beds occupied, and polyclinics were budgeted according to "capacity", meaning the number of patient visits its facility and staff were capable of handling. (Twigg 1998, 584) 
These funding methods incentivised under-treatment in secondary institutions (polyclinics) and over-treatment in tertiary institutions (hospitals), while primary care and public health services were largely neglected.

\section{The Second Trigger: Second World War and the Beginning of the Cold War, 1945-1947}

Again, the devastation of war, this time the Second World War, strained the Soviet healthcare system. After the end of the war, the situation improved only partially. With the beginning of the "Cold War", welfare modernisation was also only a low priority, resources were spread too thinly, and the increased isolationism kept medical innovations out (Williams 2006, 216). Nevertheless, quality in the healthcare sector was part of the Soviet desire to surpass the capitalist West wherever possible. The Soviets placed strong emphasis on quantitative targets based on input, leading to one of the highest number of physicians and hospital beds per unit of population in the world. At the same time, the health system was chronically underfunded, resulting in, for instance, a general lack of pharmaceuticals: "In the race for quantity in the number of doctors, nurses, hospitals, and beds, the quality of these assets was not a primary concern" (Rowland and Telyukov 1991; quote Schecter 1992, 209).

Nevertheless, the Second World War led to the spatial expansion of the Semashko model throughout Central and Eastern Europe (i.e. all territories occupied by the Soviet army except Austria). There, the Soviet Union imposed its own social system, even though there was no "preconceived plan for the erection of a bloc of countries with Soviet-style systems" as a new international order (Naimark 2017, 65). As "Moscow offered few explicit orders about how to build new administrations or how to work with existing civilian authorities in newly liberated territories", Soviet military and political leaders in the occupied countries adopted Soviet policies from home as "best practices" for the organisation of societies, polities and economies (Naimark 2017, 66). 
Despite some general homogeneity of the various stages of this "Sovietisation", the process was country-specific: it

did not occur at the same pace in every country of the region nor did its processes penetrate each to the same degree. In some countries, there was more resistance to Sovietization from "domestic" communists, who tended to propound programs that suited their nationalist inclinations. In others, modernizing elites, both communist and noncommunist, supported Soviet programs that emphasized the need for rapid industrial and technological transformations. (Naimark 2017, 67)

Thus, while all the previous healthcare systems were transformed according to the Semashko model, "each country created its own variation on the Soviet original" (Marrée and Groenewegen 1997, 10). Nevertheless, all healthcare sectors were an integral part of the planned economy and characterised by state monopoly and bureaucratic centralisation. Because all governments gave the health sector a low priority, the constant lack of funding resulted in "poor quality of the provisions and [...] technical backwardness" (Kornai and Eggleston 2001, 135-136, 139, quote 137).

In Czechoslovakia, for example, a socialist government re-installed in 1948 the Bismarckian healthcare system of the inter-war period. However, the country was forced to adopt the Soviet healthcare model in 1951/1952. "A specific element of the socialist Czechoslovak health care sector, however, was the clustering of health activities in 'Institutes of National Health' at the district and regional level" (Marrée and Groenewegen 1997, 53, quote 10). Like in the Soviet Union, the introduction of the Semashko model resulted in significant improvements in the Czechoslovak health sector, mainly in the pooling of healthcare financing, the extension of coverage and a significant increase in the number of healthcare facilities. In the early 1950s, "malnutrition, the high infant mortality rates, and the incidence of serious infections such as tuberculosis diminished rapidly". By the 1960s, Czechoslovakia's health status was regarded as very good in international terms, an era considered as "the golden age" of the country's health sector (Popić 2014, 122, quote 124). 


\section{Crisis of the Semashko System}

However, the inbuilt weaknesses of the Semashko system were already by this time becoming visible in the Soviet Union. Since the mid-1960s, health conditions deteriorated with stagnating life expectancy and high mortality rates; striking disparities in health status and outcomes existed among the fifteen Soviet republics. The many problems facing the Soviet healthcare system were caused by chronic underfunding, antiquated and deteriorating health facilities, dramatic shortages of pharmaceuticals and equipment, overcrowding, and an exodus of skilled health professionals (Rowland and Telyukov 1991, 71-72; Williams 2006, 217). Overall, the Semashko healthcare system had only been able "to satisfy the early demands for better health care by staving off infections, epidemics, famines, and terribly unsanitary conditions" (Schecter 1992, 210). However, it was much less effective in the areas of non-communicable diseases and so failed to advance the health of the population and improve health services further (Rowland and Telyukov 1991, 76). Terris $(1988,539)$ argues that isolation of the Soviet Union during the Cold War "made it difficult to keep up with the great advances in noninfectious disease epidemiology and prevention in the United States and Great Britain”.

Thus, in the mid-1980s, the Soviet leadership came to realise that the Semashko system needed some fundamental changes, that is, the introduction of quasi-market elements. Reform efforts in the late 1980s resulted in several regional pilot projects introducing a mandatory health insurance scheme to improve the financial situation of the healthcare sector. Polyclinics became fundholders referring patients to hospitals when necessary and paying for these treatments, and patients could choose their clinic and general practice physician (Twigg 1998, 585).

The essence of the plan (was) to move away from the centrally controlled and fully public system to a system of mixed financing with more responsibility given to republics and communities. In response to the government's previous inability to finance medical care at sufficient levels out of the government budget, the new plan would seek revenues from a variety of sources, drawing on contributions from the enterprises in their role as 
employers and limited out-of-pocket payments by individuals. (Rowland and Telyukov 1991, 84)

Even though considered successful, the break-up of the Soviet Union in 1991 prevented the wider expansion of these pilot projects and a fundamental change to the Semashko healthcare system (Twigg 1998, 585-586).

The deficiencies of the Semashko model were "duplicated in practically all of the socialist countries, since they tend to follow the Soviet example; practically all of them (lagged) badly in the prevention of noninfectious diseases" (Terris 1988, 539). For example, by the end of the 1960s, the positive trend in Czechoslovakia turned as health status indicators started to stagnate before they deteriorated: "By the 1980s, the situation had become alarming" (Popić 2014, 125). This trajectory in Czechoslovakia was also found in the rest of the region. Efforts to reform the deteriorating healthcare systems and shift away from the Semashko model were also undertaken in Central and Eastern Europe; however, before 1989-1990, notable changes began to emerge only in Hungary and Poland (Kornai and Eggleston 2001, 140-141).

\section{Conclusion}

The socialist healthcare model, named after its main proponent Nikolai A. Semashko, was the predominant medical care system in Central and Eastern Europe for decades. The first universal coverage of free, basic healthcare in the world was brought into existence by war, and war enabled its spatial expansion throughout Central and Eastern Europe. Armed conflict was the starting point for both its creation and its expansion through fundamental institutional reconfigurations domestically and, later, internationally (Obinger et al. 2018). The effects of war, causing internal refugee flows, epidemics, famine, and, after the First World War, also civil war and institutional disruption, created a demand but also extremely difficult starting conditions for any healthcare system. Additionally, the effects of war had direct repercussions on the healthcare system in the form of a lack of qualified healthcare personnel, funding, 
equipment and pharmaceuticals, and the war-related destruction of healthcare facilities and infrastructure. Furthermore, the Soviet governments gave healthcare a low priority and were most of the time preoccupied with (armed) conflicts.

The socialist experiment with a fully socialised healthcare system was well suited to deal with this severe situation. But while the Semashko system was able to improve basic healthcare provision for the large majority of people (especially in the post-war periods), it was not able to adequately satisfy more demanding healthcare needs and the healthcare needs created by modern industrialised societies. Notwithstanding the fact that the original ideal of universal coverage was never realised, its main crux was probably that "(a)ccess and distribution are determined by need, in accordance with central planning norms" (George and Manning 1980, 112). However, needs cannot be planned. Additionally, social needs were generally subordinated to economic needs; as a result, economic policy always has determined health policy in the Soviet Union and, after the Second World War, in Central and Eastern Europe as well. However, the underlying principles of the Semashko healthcare system had a huge impact on the global discussion on healthcare organisation and finance. Its legacies still influence healthcare policies in this region today.

Acknowledgements This chapter is a product of the research conducted in the Collaborative Research Center "Global Dynamics of Social Policy" at the University of Bremen. The centre is funded by the Deutsche Forschungsgemeinschaft (DFG, German Research Foundation)—project number 374666841-SFB 1342.

\section{References}

Davis, Christopher M. 1990. Economics of Soviet Public Health, 1928-1932. In Health and Society in Revolutionary Russia, ed. Susan G. Solomon and John F. Hutchinson, 146-172. Bloomington: Indiana University Press. George, Vic, and Nick Manning. 1980. Socialism, Social Welfare and the Soviet Union. London: Routledge \& Kegan Paul. 
Kornai, Jànos, and Karen Eggleston. 2001. Welfare, Choice, and Solidarity in Transition: Reforming the Health Sector in Eastern Europe. Cambridge: Cambridge University Press.

Krementsov, Nikolai. 2017. The Promises, Realities, and Legacies of the Bolshevik Revolution, 1917-2017. American Journal of Public Health 107 (11): 1693-1694.

Marrée, Jörgen, and Peter P. Groenewegen. 1997. Back to Bismarck: Eastern European Health Care Systems in Transition. Aldershot: Avebury.

Naimark, Norman. 2017. The Sovietization of East Central Europe 1945-1989. In The Cambridge History of Communism. Vol. II: The Socialist Camp and World Power 1941-1960s, ed. Norman Naimark, Silvio Pons, and Sophie Quinn-Judge, 63-86. Cambridge: Cambridge University Press.

Obinger, Herbert, Klaus Petersen, and Peter Starke. 2018. Introduction: Studying the Warfare-Welfare Nexus. In Warfare and Welfare: Military Conflict and Welfare State Development in Western Countries, ed. Herbert Obinger, Klaus Petersen, and Peter Starke, 1-35. Oxford: Oxford University Press.

Popić, Tamara. 2014. Policy Learning, Fast and Slow: Market Oriented Reforms of Czech and Polish Healthcare Policy, 1989-2009. PhD diss., European University Institute, Florence.

Rimlinger, Gaston V. 1971. Welfare Policy and Industrialization in Europe, America, and Russia. New York: Wiley \& Sons.

Rowland, Diane, and Alexandre V. Telyukov. 1991. Soviet Health Care from Two Perspectives. Health Affairs 10 (3): 71-86.

Schecter, Kate. 1992. Soviet Socialized Medicine and the Right to Health Care in a Changing Soviet Union. Human Rights Quarterly 14 (2): 206-215.

Solomon, Susan G., and John F. Hutchinson. 1990. Introduction: The Problem of Health Reform in Russia. In Health and Society in Revolutionary Russia, ed. Susan G. Solomon and John F. Hutchinson, ix-xiv. Bloomington: Indiana University Press.

Terris, Milton. 1988. Restructuring and Accelerating the Development of the Soviet Health Service: Preliminary Observations and Recommendations. Journal of Public Health Policy 9 (4): 537-543.

Twigg, Judyth L. 1998. Balancing the State and the Market: Russia's Adoption of Obligatory Medical Insurance. Europe-Asia Studies 50 (4): 583-602.

Weissman, Neil B. 1990. Origins of Soviet Health Administration: Narkomzdrav, 1918-1928. In Health and Society in Revolutionary Russia, ed. Susan 
G. Solomon and John F. Hutchinson, 97-120. Bloomington: Indiana University Press.

Williams, Christopher. 2006. The Modernisation of Russian Health Care: Challenges, Policy, Constraints. In Modernisation in Russia since 1900, ed. Markku Kangaspuro and Jeremy Smith, 206-220. Finnish Literature Society.

Open Access This chapter is licensed under the terms of the Creative Commons Attribution 4.0 International License (http://creativecommons.org/licenses/ by/4.0/), which permits use, sharing, adaptation, distribution and reproduction in any medium or format, as long as you give appropriate credit to the original author(s) and the source, provide a link to the Creative Commons licence and indicate if changes were made.

The images or other third party material in this chapter are included in the chapter's Creative Commons licence, unless indicated otherwise in a credit line to the material. If material is not included in the chapter's Creative Commons licence and your intended use is not permitted by statutory regulation or exceeds the permitted use, you will need to obtain permission directly from the copyright holder.

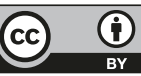

